Original Article

\title{
PHARMACOGNOSTIC AND HPTLC BASED COMPARATIVE STUDY ON LEAVES OF MERREMIA EMARGINATA BURM. F. AND CENTELLA ASIATICA (L.) URBAN
}

\author{
MANJU K. C. ${ }^{1}$, ANITHA JOHN ${ }^{2}$, SAKKEENA A. ${ }^{3}$, GAYATHRI DEVI V. ${ }^{2}$, NEETHU KANNAN B. ${ }^{4}$, KANAGARAJAN A. ${ }^{5}$
}

${ }^{1}$ Senior Research Fellow (Botany), ${ }^{2}$ Research Officer (Chemistry), ${ }^{3}$ Senior Research Fellow (Chemistry), ${ }^{4}$ Research Assistant (Botany),

${ }^{5}$ Assistant Director (Siddha), Siddha Regional Research Institute, Poojappura, Thiruvananthapuram, Kerala

Email: anithamariam63@gmail.com

Received: 16 Feb 2019, Revised and Accepted: 11 Apr 2019

\begin{abstract}
Objective: In this study, an attempt was made to generate information based on botanical, physicochemical and HPTLC data needed for proper identification and authentication of $M$. emarginata and $C$. asiatica belonging to two different families.

Methods: Botanical study comprises of macroscopy, microscopy and powder microscopy of leaves of both crude drugs. The physicochemical parameters such as water-soluble extractive, alcohol soluble extractive and loss on drying at 105?, total ash, acid insoluble ash, and volatile oil were determined according to standard methods. HPTLC studies of chloroform extracts of leaves of both drugs were conducted at $254 \mathrm{~nm}$, $366 \mathrm{~nm}$ and $575 \mathrm{~nm}$ after derivatisation using vanillin-sulphuric acid and the results were documented.

Results: The present study reveals that microscopy and most of the physicochemical parameters of both the plant materials are different. Anatomy of the leaves showed two main characteristic differences. First plenty of trichome with trichome base and calcium oxalate crystal is common in $M$. emarginata, which is not observed in C. asiatica. Both plants have different venation patterns and leaf constants. The total ash content and the solubility in alcohol and water for leaves of $C$. asiatica are higher than that of M. emarginata. The HPTLC fingerprinting pattern obtained for both
\end{abstract} drugs are different.

Conclusion: All the results obtained from this study help in determining differences and similarities of leaves of $M$. emarginata and C. asiatica and thereby preventing adulteration and substitution and emphasizing the importance of standardization.

Keywords: Merremia emarginata, Centella asiatica, Morphological characters, Microscopy, Physico-chemical analysis and HPTLC fingerprinting

(C) 2019 The Authors. Published by Innovare Academic Sciences Pvt Ltd. This is an open-access article under the CC BY license (http://creativecommons.org/licenses/by/4.0/) DOI: http://dx.doi.org/10.22159/ijcpr.2019v11i3.34092

\section{INTRODUCTION}

Merremia emarginata Burm. F (Convolvulaceae) and Centella asiatica (L.) (Apiaceae) are two important drugs mentioned in Siddha system of medicine. $M$. emarginata and $C$. asiatica are perennial, much-branched creepers. M. emarginata is also known as Ipomoea renifomis and it is widely distributed all over India, especially in damp places and railway tracks. C. asiatica is locally known as Vallarai. It is found throughout India growing in moist places up to an altitude of $1800 \mathrm{~m}$. About 20 species grow in most parts of the tropic or wet pantropical areas such as rice paddies, and also in rocky, higher elevations [1]. These plants have different vernacular names [2-3] (table 1).

Both plants have been used as a medicine in India since ancient time. $M$. emarginata has been claimed to be useful for cough, headache, neuralgia, rheumatism, diuretic, inflammation, troubles of the nose, and fever due to enlargement of the liver and also for treating cancer. C. asiatica widely known as Brahmi has been used as a rasayana (adaptogenic) drug since ancient time for enhancing cognitive function by revitalizing the nerve and brain cells. It has been used for revitalizing the nerves and brain cells, hence primarily known as a "Brain food" or "Memory enhancer"in India [4]. It is commonly known as mandukparni or Indian pennywort or jalbrahmi [5]. In China, known as gotukola, it is one of the reported "miracle elixirs of life" known over 2000 y ago [6].

Both plants resemble externally. The similar morphological characteristics of the leaves of both herbs with subtle differences lead to substitution. These are also frequently adulterated or substituted with other species. In this study an attempt was made to generate information based on botanical, physicochemical and HPTLC data needed for proper identification and authentication of $M$. emarginata and $C$. asiatica belonging to two different families.

Table 1: Vernacular name of M. emarginata and C. asiatica

\begin{tabular}{llll}
\hline S. No. & Regional language & M. emarginata & C. asiatica \\
\hline 1 & Tamil & Elikkathilai & Vallarai \\
2 & Malayalam & Elichevi & Kudangal \\
3 & Sanscrit & Akhuparni & Mandukaparni \\
4 & Kannada & Althigida & Brahmisoppu \\
5 & Hindi & Muskani & Ballari \\
\hline
\end{tabular}

\section{MATERIALS AND METHODS}

\section{(A). Plant material}

The fresh leaves of M. emarginata and C. asiatica were collected and authenticated. The plant materials were cut, crushed dried, and kept in airtight containers and used for all other experimental purposes. The fresh samples were used for anatomical studies.

\section{(B). Macroscopy}

Macroscopic characters of leaves of M. emarginata and C. asiatica were recorded systematically. The arrangement, size, shape, base, 
texture, margin, apex, venation, colour, odour, taste of leaves were observed. Macroscopic characters were studied [7].

\section{(C). Microscopy}

Microscopic studies of both plant materials were carried out by preparing thin sections of leaves. The thin sections were further washed with water, stained with safranin and mounted in glycerine for observation [8].

\section{(D). Powder microscopy}

The powder microscopy of the powered leaves of both drugs was studied using standard procedure [9] by capturing the images of different fragments of tissues and diagnostic characteristic features were recorded.

\section{(E). Determination of leaf constants}

A number of leaf measurements are used to distinguish some closely related species not easily characterized by general microscopy. Stomatal number, stomatal index, palisade ratio, trichome number, vein islet and veinlet termination of leaves of both plants were observed under $4 \mathrm{X}, 20 \mathrm{X}$ objective of the microscope as per standard protocol.

\section{(F). Physico-chemical study}

The physicochemical parameters such as ash content, acid insoluble ash, volatile oil, solubility in water and alcohol, loss on drying at $105^{\circ} \mathrm{C}$ and foreign matter were determined as per WHO guidelines [10].

\section{(G). High-performance thin layer chromatographic analysis (HPTLC)}

HPTLC is an invaluable quality assessment tool for the evaluation of botanical materials and is the simplest separation technique today available to the analyst [11]

\section{a. Preparation of extract of the drug materials for HPTLC analysis}

$4 \mathrm{gm}$ each of the dried and powdered leaves of M. emarginata and C. asiatica was soaked in $40 \mathrm{ml}$ chloroform at room temperature for overnight. The contents were filtered through separate filter papers and each filtrate was concentrated on a water bath to $4 \mathrm{ml}$. These extracts were used for chromatographic studies [12].

\section{b. Development of HPTLC}

$4 \mu \mathrm{l}$ and $8 \mu \mathrm{l}$ of chloroform extract of each plant material were spotted in the form of bands with Camag microliter syringe on a precoated silica gel $60 \mathrm{~F}_{254}$ (Merck) plates with Automatic TLC Sampler 4 (ATS4). Mobile phase selected for the study was Toluene: Ethyl acetate: Formic acid (6: 2: 0.1). Linear ascending development was done in twin trough glass chamber saturated with the specified mobile phase. The plate was air dried and kept under UV $254 \mathrm{~nm}$ and $366 \mathrm{~nm}$ and white light after derivatization using vanillinsulphuric acid reagent and photo documentation were done. The plates were scanned at UV $254 \mathrm{~nm}, 366 \mathrm{~nm}$ and $575 \mathrm{~nm}$ after derivatization using TLC Scanner 4 with win CATS software for interpretation of data.
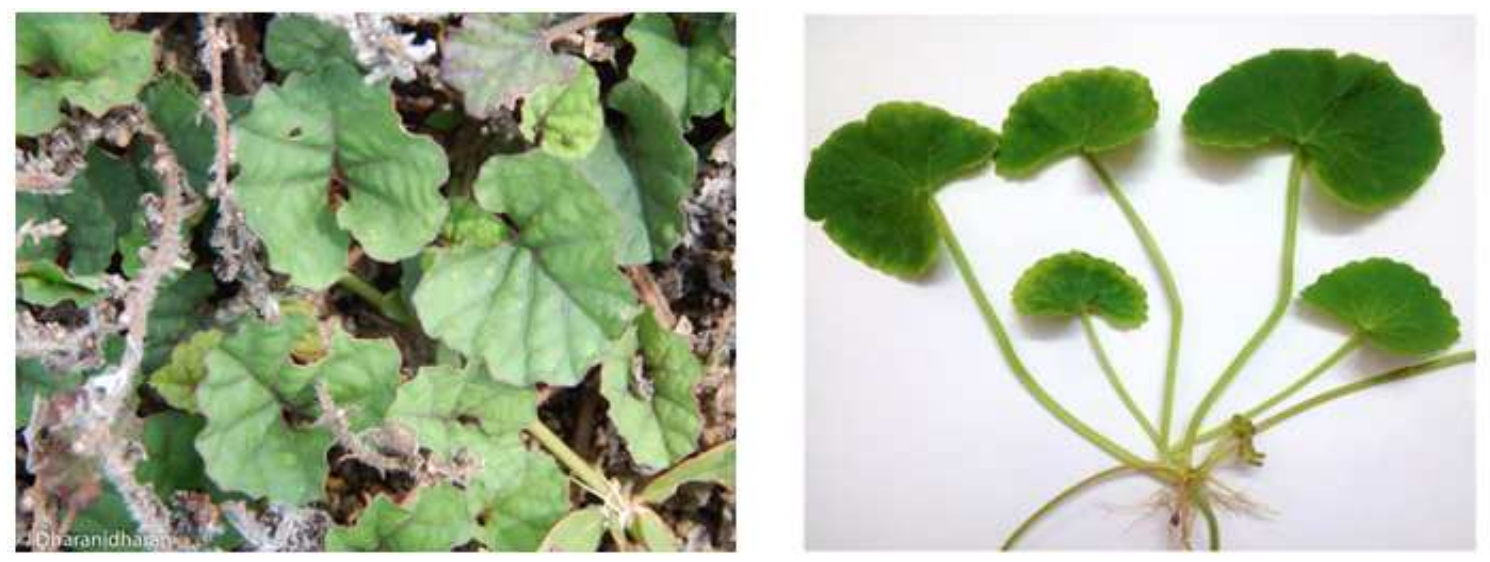

Fig. 1: Habit (a) M. emarginata, (b) C. Asiatica

\section{RESULTS AND DISCUSSION}

\section{(A). Macroscopic characters}

Morphology of leaves of M. emarginata and C. asiatica are discussed below M. emarginata is sometimes confused with $C$. asiatica which has the same habit. (fig. 1.) These are clonal perennial and prostrate. M. emarginata has slender stems $30-75 \mathrm{~cm}$ long that usually form roots at the nodes. Leaves alternate, reniform to broadly ovate, $0.3-3$ $\mathrm{cm}$ long. Often slightly wider, cordate with broadly rounded sinus and a basal lobes entire, glabrous. Yellow flowers with very short peduncle, capsular, fruits with black seeds. Habitat is in open grasslands and fields, along railroads and waste places.

C. asiatica is faintly aromatic, stoloniferous, creeper herb, flourishes extensively in shady, marshy, damp and wet places such as paddy fields, river banks forming a dense green carpet. Leaves of $C$. asiatica are cordate or hastate, 1-3 from each node of stems, long petioled, 2$6 \mathrm{~cm}$ long and $1.5-5 \mathrm{~cm}$ wide, orbicular-reniform, sheathing leaf base, crenate margins, glabrous on both sides, leaf blades are, crenate with thick radiate veins, pink flowers with umbel inflorescence. Fruits of $C$. asiatica are compressed mericarps. Using this distinction, the plant material with small globose fruit capsules was identified as $M$. emarginata [13]. The leaves of $M$. emarginata are consumable as pot-herb [14]. In Salem district it is consumed in the name of Vallarai with the consumers expecting the benefits of $C$. asiatica.

\section{(B). Microscopy}

The T. S of M. emarginata and C. asiatica leaves were differentiated in to epidermis, mesophyll and vascular tissues. In M. emarginata the epidermal layer consists of semi-circular, thin walled cells with thick cuticle on the flat outer tangential wall. But in C. asiatica both epidermises were uniseriate, composed of compactly arranged rectangular cells with moderately striated outer walls. Cuticle appeared either completely absent or poorly developed in $C$. asiatica. Non-cuticular striated epidermis which may facilitate the steady absorption of water from the surrounding [15]. Beneath the epidermis of the M. emarginata small cluster of collenchymatous cells is located in the adaxial conical part. In C. asiatica abaxial epidermis contained a patch or band of sclerenchymatous tissues. Anomocytic stomata were embedded throughout the upper and lower epidermis of $M$. emarginata but paracytic in C. asiatica. Many of which contain crystals of calcium oxalate. In C. asiatica mesophyll having a compact palisade parenchyma with one layer of elongated, and barrel shaped cells and 
oval to rectangular spongy parenchyma cells with wide intercellular spaces. A parenchymatous bundle sheath was encircled the vascular strand. In M. emarginata 2 to 3 layers of elongated palisade cells and spongy mesophyll with loosely arranged cells. Bicollateral bowl shaped vascular bundle. In both cells of the mesophyll were found filled with plenty of chloroplasts (fig. 3).
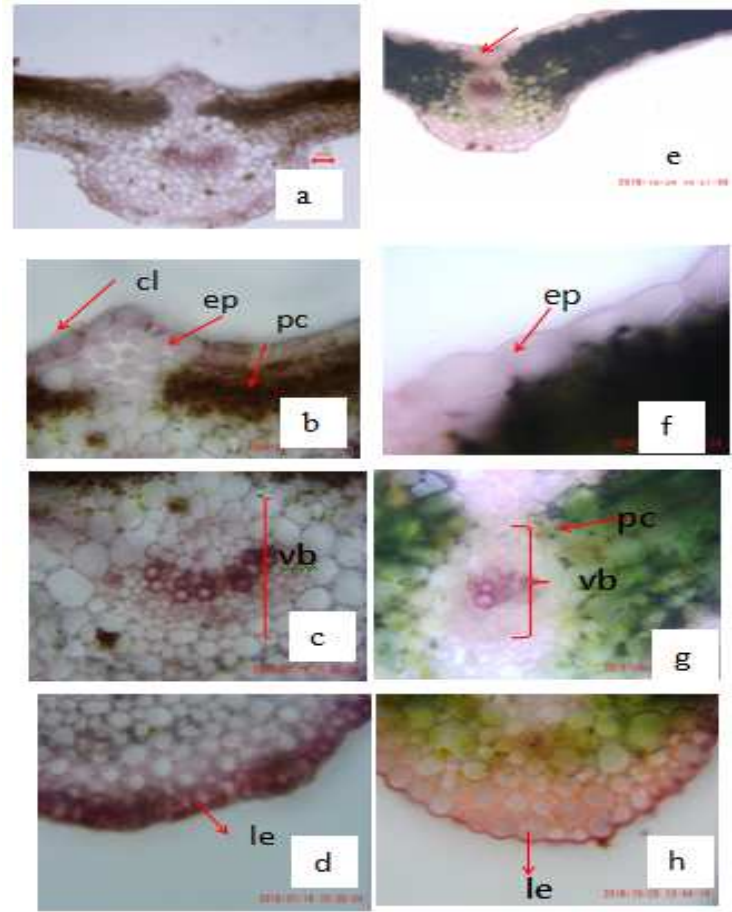

Fig. 2:T. S of Leaf (1) M. emarginata (a-d) (2) C. asiatica (e-h), aande: portion enlarged, b: Cuticle ( $\mathrm{cl}$ ), epidermis (ep), palisade cell (pc), c: vascular bundle (vb), dandh: lower epidermis (le), f: epidermis (ep), g: vascular bundle (vb), palisade cell (pc)

T. S of M. emarginata petiole was semi-circular on the abaxial side and the adaxial side has wide shallow concavity. Petiole of $C$. asiatica had a pentagonal shape and dorsiventeral differentiation. Trichome with thin epidermal layer was followed by collenchyma and parenchymatous ground tissue in M. emarginata. In C. asiatica trichomes are absent and a prominent enteral hollow core of air canal present. Bicollateral bundles are centrally located in $M$. emarginata. But in C. asiaticafive vascular bundles were arranged in the corner. Vascular tissues form a continuous cylinder with a periphloematicsclereids arch over each vascular strand. Crystal idioblasts were embedded in the cortical parenchyma of the $C$. asiatica petiole (fig. 4)
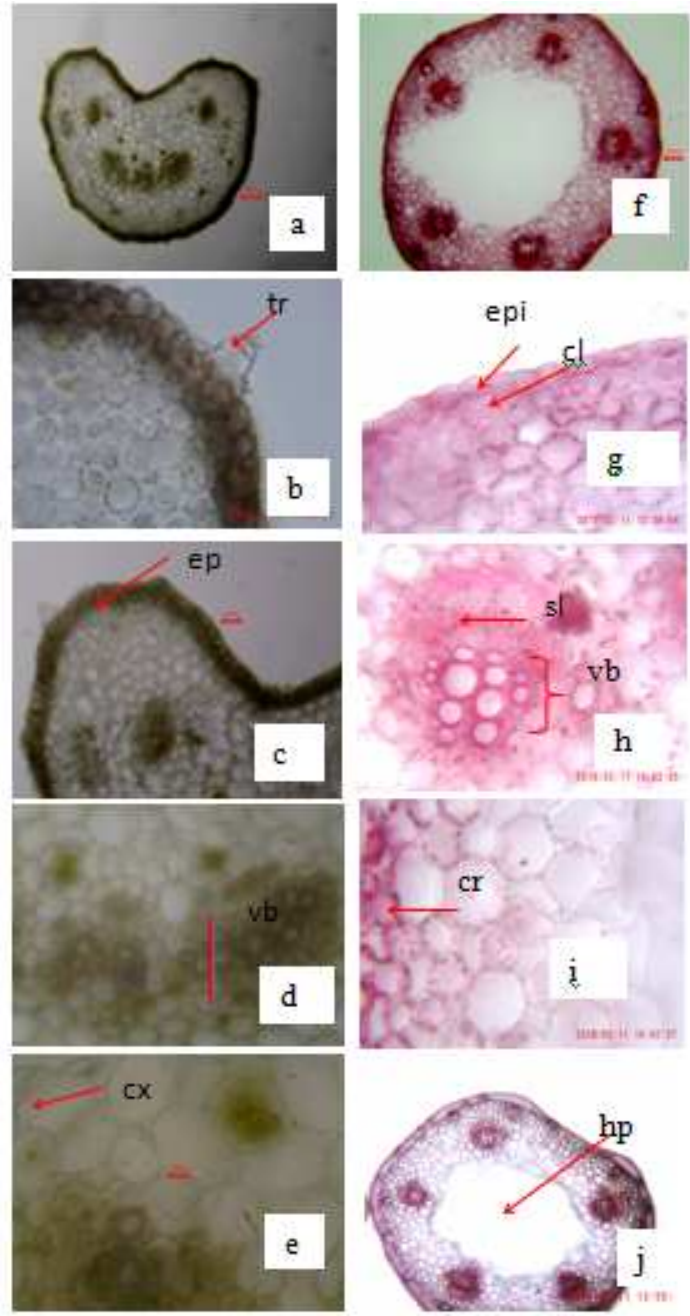

Fig. 3: T. S of Petiole (1) M. emarginata (a-e) (2) C. asiatica (f-j), aandf: enlarged portion, b: trichome (tr), c: epidermis (ep), $d$ : vascular bundle, e: cortex (cx), g: epidermis (ep), collenchyma (cl), h: vascular bundle (vb), sclereids (sl), i: crystal (cr), j: hollow pith

\section{(C). Powder microscopy}

Powder microscopy of leaves of M. emarginata and C. asiatica showed in fig. 5. M. emarginata and C. asiatica were differentiated into various characters. Different types of trichomes, such as glandular and warty trichomes and anomocytic stomata were noted in M. emarginata. Whereas in C. asiatica, trichomes were absent and paracytic stomata present. Calcium oxalate crystals present only in M. emarginata.
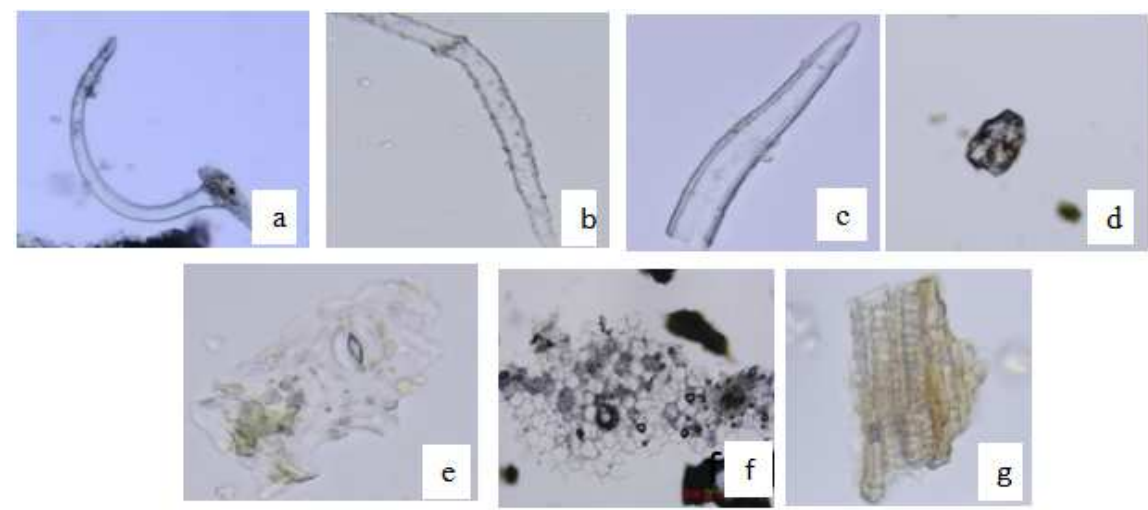

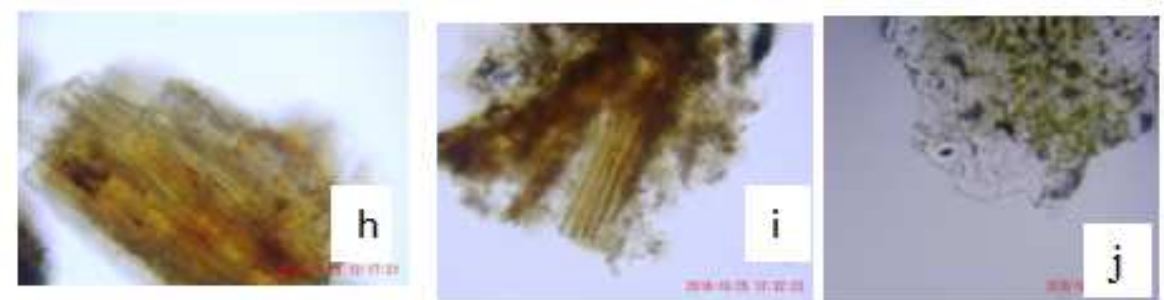

2

Fig. 4: Powder microscopy (1) M. emarginata (a-g) (2) C. asiatica (a-c), a-c: trichomes, d: calcium oxalate crystal, e: anomocytic stomata, f: spongy parenchyma with chloroplast, gandi: tracheid with spiral thickening, h: parenchyma cell, j: paracytic stomata

\section{(D). Determination of leaf constants}

Leaf constants of M. emarginata and C. asiatica are showed in fig. 6 and table 2
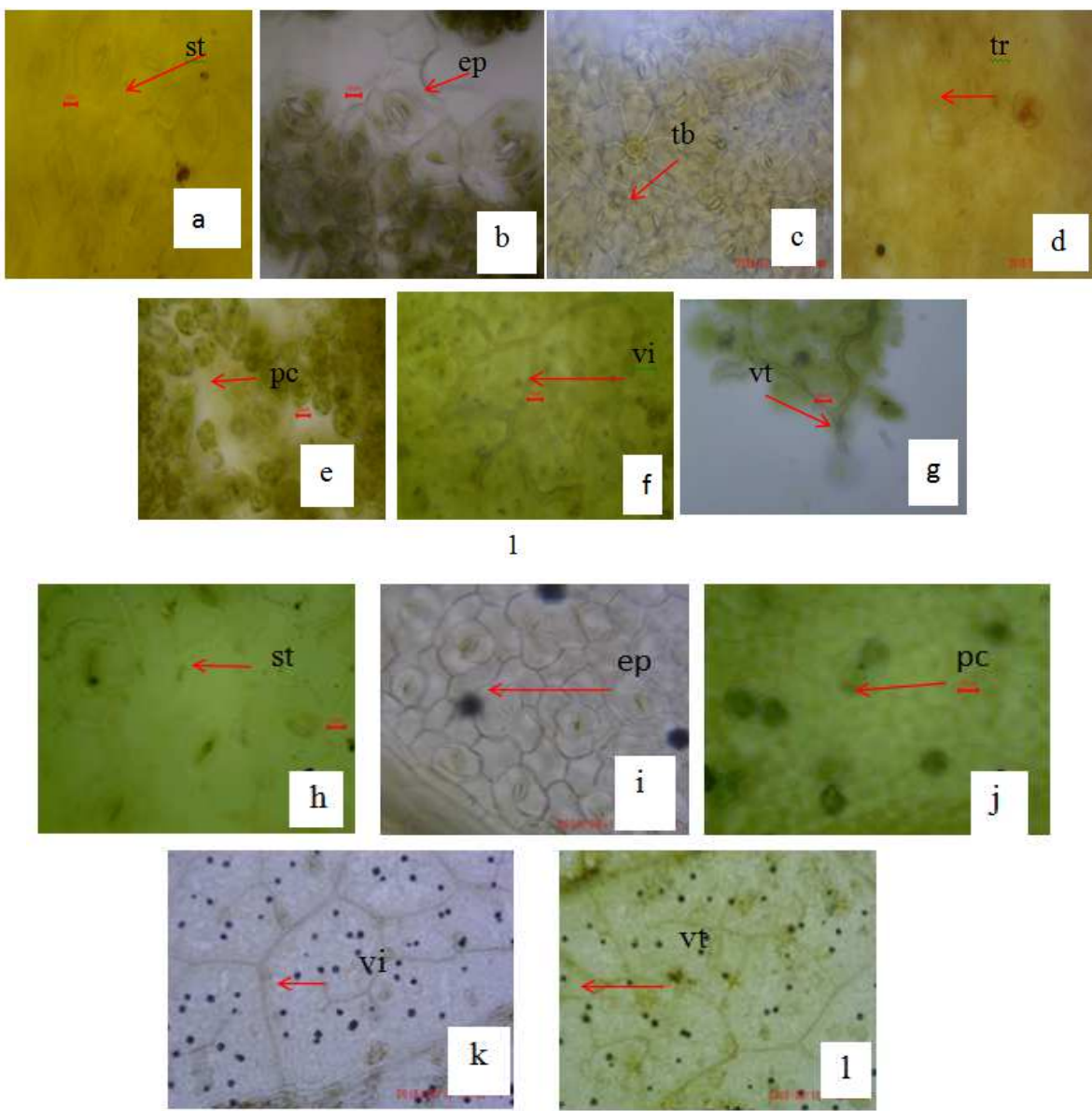

2

Fig. 5: Leaf constants (1) M. emarginata (a-g) (2) C. asiatica (h-l), a: anomocytic stomata (st), bandi: epidermis (ep), c: trichome with base (tb), d: trichome, eandj: palisade cell (pc), fandk: vein islet (vi), gandl: veinlet termination (vt), h: paracytic stomata

Table 2: Leaf constants of M. emarginata and C. asiatica

\begin{tabular}{llll}
\hline S. No. & Parameters & M. emarginata & C. asiatica \\
\hline 1 & Stomatal no. & 10 & 10.6 \\
2 & Stomatal index & 21.4 & 22.3 \\
3 & Palisade ratio & 4.1 & 2 \\
4 & Epidermal no. & 146.6 & 69 \\
5 & Vein-islet no. & 52 & 20 \\
6 & Veinlet termination & 42.6 & 40 \\
7 & Trichome no. & 14.6 & Nil \\
\hline
\end{tabular}

M. emarginata and C. asiatica have some morphological similar characters and different anatomical characters. Comparison of morpho-anatomical characters is showed in the table 3. 
Table 3: Comparison of morpho-anatomical characters

\begin{tabular}{|c|c|c|c|}
\hline S. No. & Characters & M. emarginata & C. asiatica \\
\hline 1 & Habit & Branched herb (creeper) & Branched herb (creeper) \\
\hline \multirow[t]{7}{*}{2} & Macroscopy & & \\
\hline & Root & Taproot & Tap root \\
\hline & Stem & Pubescent, glabrous & Reddish, glabrous \\
\hline & Leaf & Simple alternate, reniform to broadly ovate & Simple alternate, reniform elongated petiole. \\
\hline & Flower & Yellow colour & Pink colour \\
\hline & Inflorescences & Axillary & Umbel \\
\hline & Fruit & Fruit globes capsule & Cremocarp \\
\hline \multirow[t]{11}{*}{3} & Microscopy & & \\
\hline & $\begin{array}{l}\text { Leaf } \\
\text { 1. Cuticle }\end{array}$ & $\begin{array}{l}\text { Thin-walled cells with thick cuticle. Beneath } \\
\text { the epidermis }\end{array}$ & Uniseriate, Cuticle absent or poorly developed. \\
\hline & 2. Epidermis & Compactly arranged rectangular cells. & Compactly arranged rectangular cells. \\
\hline & 3. Mesophyll tissue & 2 to 3 layers of elongated palisade cell. & 2 layers of barrel-shaped palisade cell. \\
\hline & $\begin{array}{l}\text { 3. Vascular } \\
\text { bundle }\end{array}$ & Bicollateral, bowl-shaped vascular bundle. & $\begin{array}{l}\text { Bicollateral, parenchymatous bundle sheath was encircled the } \\
\text { vascular strand. }\end{array}$ \\
\hline & Petiole & & \\
\hline & 1. shape & Semi-circular & pentagonal \\
\hline & 2. trichomes & present & absent \\
\hline & 3. pith & parenchymatous & hollow pith \\
\hline & 4. Vascular bundle & 5 or 6 in number & 5 in number \\
\hline & Sclereids & Sclereids absent & Periphloematic Sclereids \\
\hline \multirow[t]{4}{*}{4} & Powder microscopy & & \\
\hline & 1. Stomata & Anomocytic & paracytic \\
\hline & 2. Trichomes & Present & absent \\
\hline & 3. Crystal & Calcium oxalate & no \\
\hline
\end{tabular}

\section{E). Physico-chemical analysis}

The results of the physicochemical analysis of leaves of $M$. emarginata and $C$. asiatica leaves are pictorially represented in table 4 . Total cash value of the plant material indicates the amount of minerals and earthy materials attached to it. Acid-insoluble ash usually represents the amount of silica present as sand and dust and indicates contamination [16]. Loss on drying at $105^{\circ} \mathrm{C}$ shows the presence of moisture content and volatile oil in the drug. The water-soluble extractive value indicates the presence of more polar constituents such as tannin, sugar, plant acid, mucilage and glycosides. The alcohol-soluble extractive values indicated the presence of phenols, alkaloids, steroids, glycosides, flavonoids etc. The water-soluble extractive value of leaf $M$. emarginata was $9.36 \%$ and that of the $C$. asiatica was $26.30 \%$. The respective alcohol-soluble extractive values (2.26 \% and $18.86 \%)$ are less when compared to water-soluble extractive values of the plant materials. Presence of volatile oil was not detected in both the plant materials. The study reveals that most of the physicochemical parameters of both plant materials are different. The extractive values in alcohol and water for $C$. asiatica was higher than that of $M$. emarginata. These values are a measure of the quantity of the chemical constituents soluble in the solvents. Ash values are also higher for $C$. asiatica indicating the presence of more inorganics in the leaf than in the leaf of M. Emarginata.

Table 4: The physicochemical parameters of M. emarginata and C. asiatica

\begin{tabular}{llll}
\hline S. No. & Parameters & M. emarginata (leaf) \\
\hline 1 & Total ash (\%) & 9.46 & C. asiatica (leaf) \\
2 & Acid insoluble ash (\%) & 1.6 & 10.38 \\
3 & Loss on drying (\%) & 14.82 & 2.1 \\
4 & Water soluble extractive (\%) & 9.36 & 8.89 \\
5 & Alcohol soluble extractive (\%) & 2.26 & nil \\
7 & Volatile oil & $<2$ & 18.86 \\
8 & Foreign Matter & & nil \\
\hline
\end{tabular}

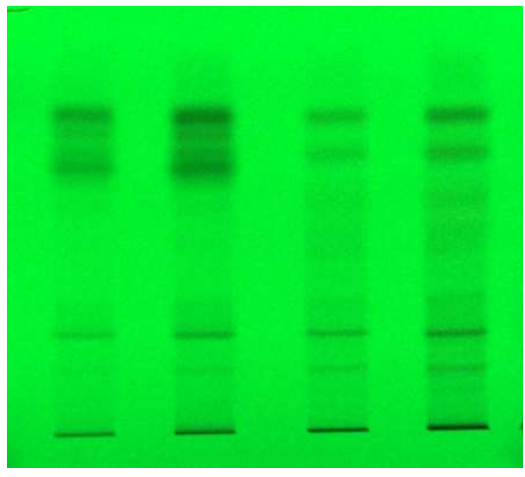

Viewed under UV 254

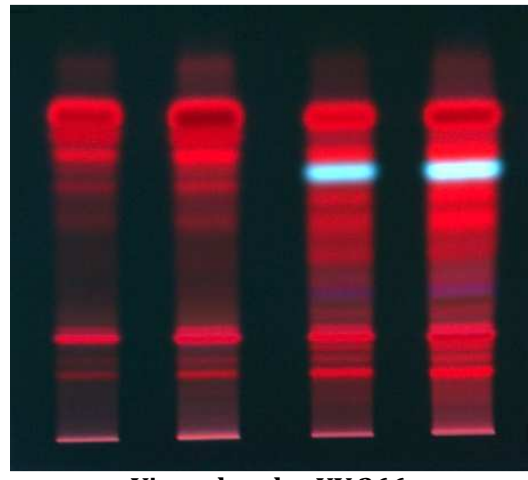

Viewed under UV 366

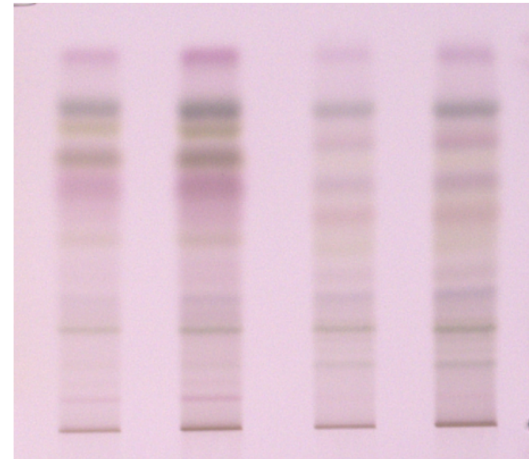

Viewed under white light after derivatisation using vanillin-sulphuric acid

Fig. 6: HPTLC photo documentation profile of the chloroform extract of leaves of $M$. emarginata and $C$. asiatica. Solvent system: Toluene: Ethyl acetate: Formic acid (6: 2: 0.1) 
(F). High-Performance thin layer chromatographic analysis (HPTLC)

\section{HPTLC photo documentation}

HPTLC photo documentation profile of the chloroform extracts of both plant materials are given in fig. 6
Track 1 and 2: $C$. asiatica; track 3 and 4: $M$. emarginata (Track 1 and 3-4 $\mu$ l each: Track 2 and 4-8 $\mu$ l each)

$\mathrm{R}_{\mathrm{f}}$ values and colour of bands of chloroform extracts of leaves of $M$. emarginata and C. asiatica under UV 254, UV 366 and UV $575 \mathrm{~nm}$ are represented in the table 5 .

Table 5: Rf values and colour of bands

\begin{tabular}{|c|c|c|c|c|c|c|}
\hline \multirow[t]{3}{*}{ Name of plant } & \multicolumn{6}{|c|}{ Wave length } \\
\hline & \multicolumn{2}{|l|}{$254 \mathrm{~nm}$} & \multicolumn{2}{|l|}{$366 \mathrm{~nm}$} & \multicolumn{2}{|c|}{$575 \mathrm{~nm}$ (after derivatization) } \\
\hline & $\mathbf{R}_{\mathrm{f}}$ values & Colour & $\mathbf{R}_{\mathrm{f}}$ values & Colour & $\mathbf{R}_{\mathrm{f}}$ values & Colour \\
\hline \multirow[t]{9}{*}{ C. asiatica (Leaf) } & 0.18 & Light green & 0.18 & Red & 0.09 & Light purple \\
\hline & 0.28 & Light green & 0.22 & Brown & 0.12 & Light purple \\
\hline & 0.74 & Dark green & 0.29 & Brown red & 0.26 & Light purple \\
\hline & 0.83 & Dark green & 0.56 & Brown & 0.35 & Light purple \\
\hline & 0.89 & Dark green & 0.65 & Bright red & 0.51 & Light yellow \\
\hline & - & - & 0.70 & Bright red & 0.66 & Purple \\
\hline & - & - & 0.78 & Bright red & 0.73 & Yellowish green \\
\hline & - & - & 0.85 & Bright red & 0.82 & Dark green \\
\hline & - & - & 0.92 & Brown & 0.96 & purple \\
\hline M. emarginata & 0.13 & Light green & 0.20 & Bright red & 0.17 & Light purple \\
\hline \multirow[t]{9}{*}{ (Leaf) } & 0.20 & Light green & 0.24 & Bright red & 0.26 & Light green \\
\hline & 0.30 & Dark green & 0.32 & Brown & 0.35 & Light purple \\
\hline & 0.66 & Light green & 0.37 & Violet & 0.49 & Light yellow \\
\hline & 0.80 & Dark green & 0.43 & Brown & 0.58 & Light purple \\
\hline & 0.90 & Dark green & 0.56 & Bright red & 0.68 & Light yellow \\
\hline & - & - & 0.62 & Fluorescent blue & 0.79 & Dark greenish \\
\hline & - & - & 0.69 & Bright red & 0.96 & Purple \\
\hline & - & - & 0.76 & Bright red & - & - \\
\hline & - & - & 0.87 & Brown & - & - \\
\hline
\end{tabular}

The HPTLC fingerprint profile and $\mathrm{R}_{\mathrm{f}}$ table of chloroform extract of leaves of $M$. emarginata and $C$. asiatica at UV $254 \mathrm{~nm}$ are shown in fig. $7(1)$ and fig. 7(2) respectively.
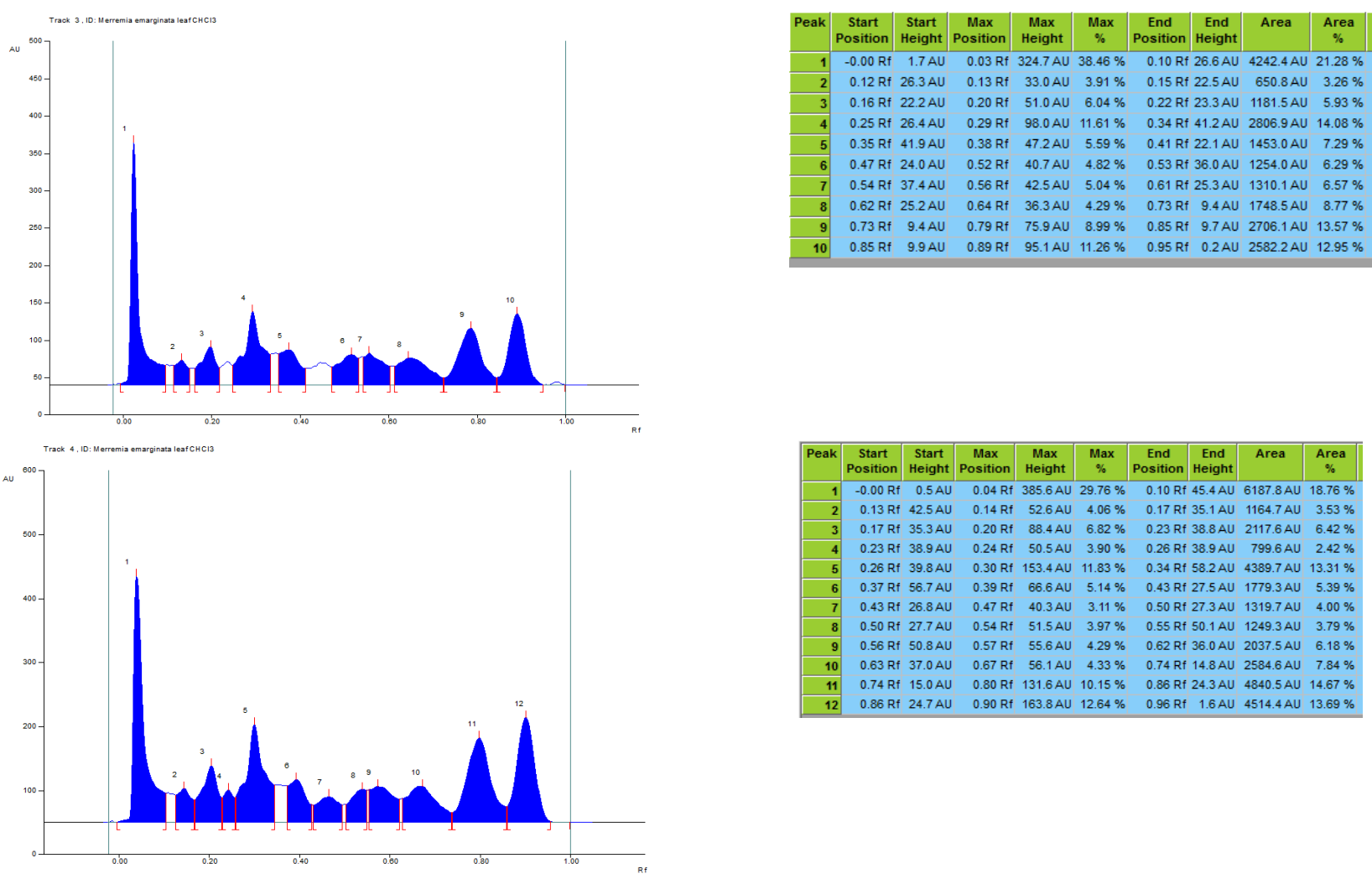

Fig. 7 (1): Fingerprint profile and $R_{f}$ table of chloroform extract of M. emarginata (leaf) at $254 \mathrm{~nm}$ 

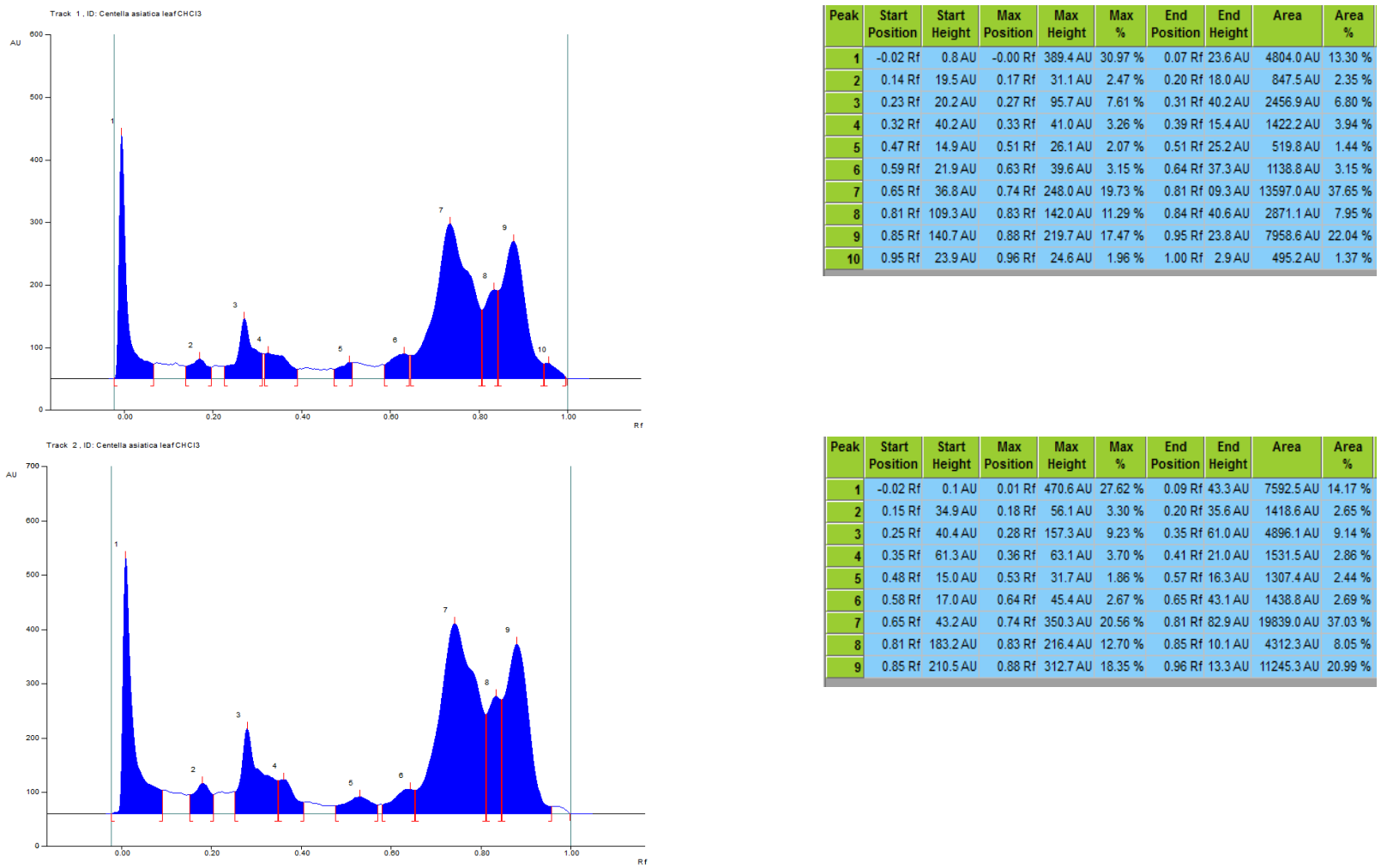

Fig. 7 (2): Fingerprint profile and $R_{\mathrm{f}}$ table of chloroform extract of $C$. asiatica (leaf) at $254 \mathrm{~nm}$

The HPTLC fingerprint profile and $\mathrm{R}_{\mathrm{f}}$ table of chloroform extract of leaves of M. emarginata and $C$. asiatica at UV $366 \mathrm{~nm}$ are represented in fig. 8(1) and fig. 8(2) respectively.
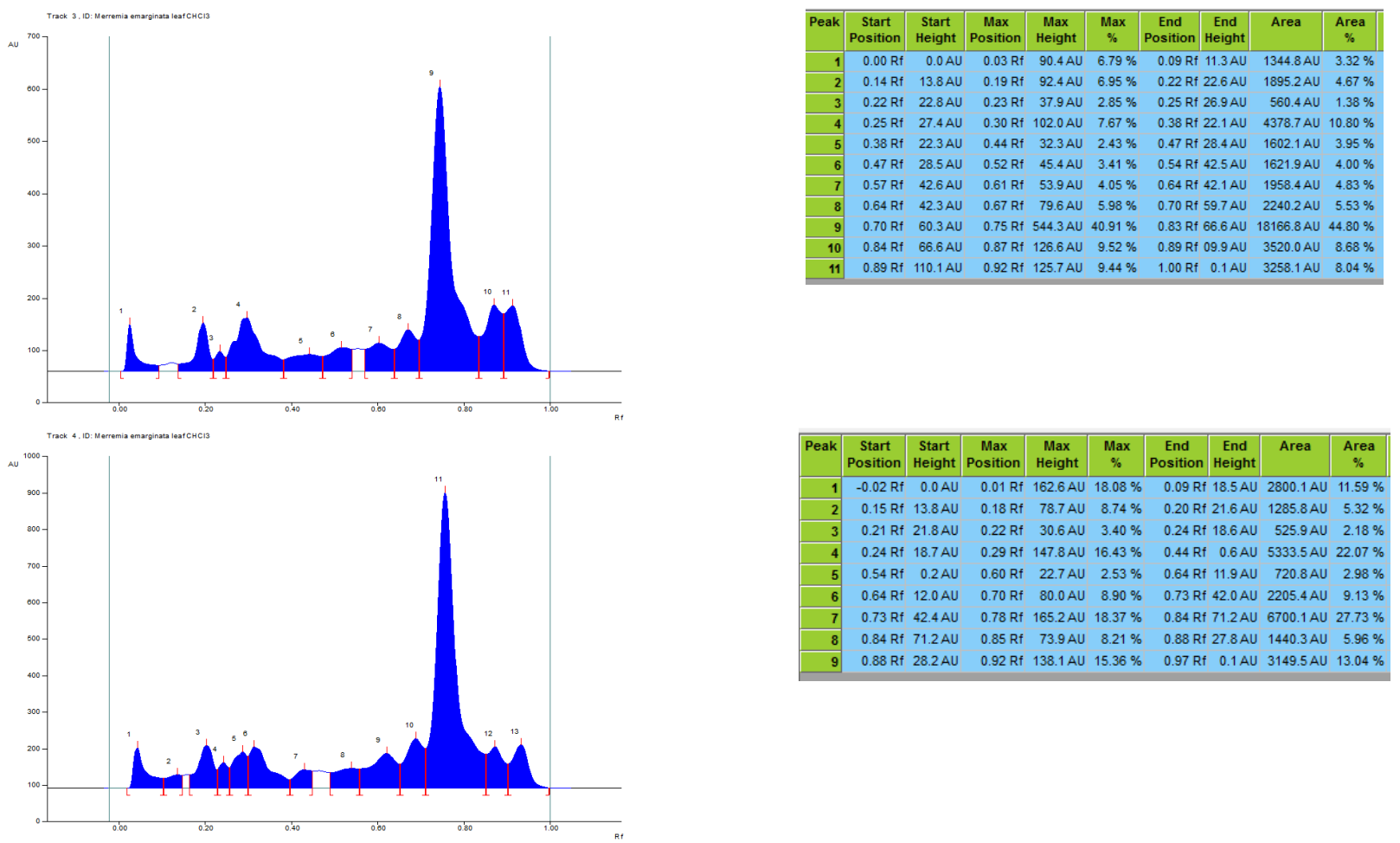

Fig. 8(1): Fingerprint profile and Rftable of chloroform extract of M. emarginata (leaf) at $366 \mathrm{~nm}$ 

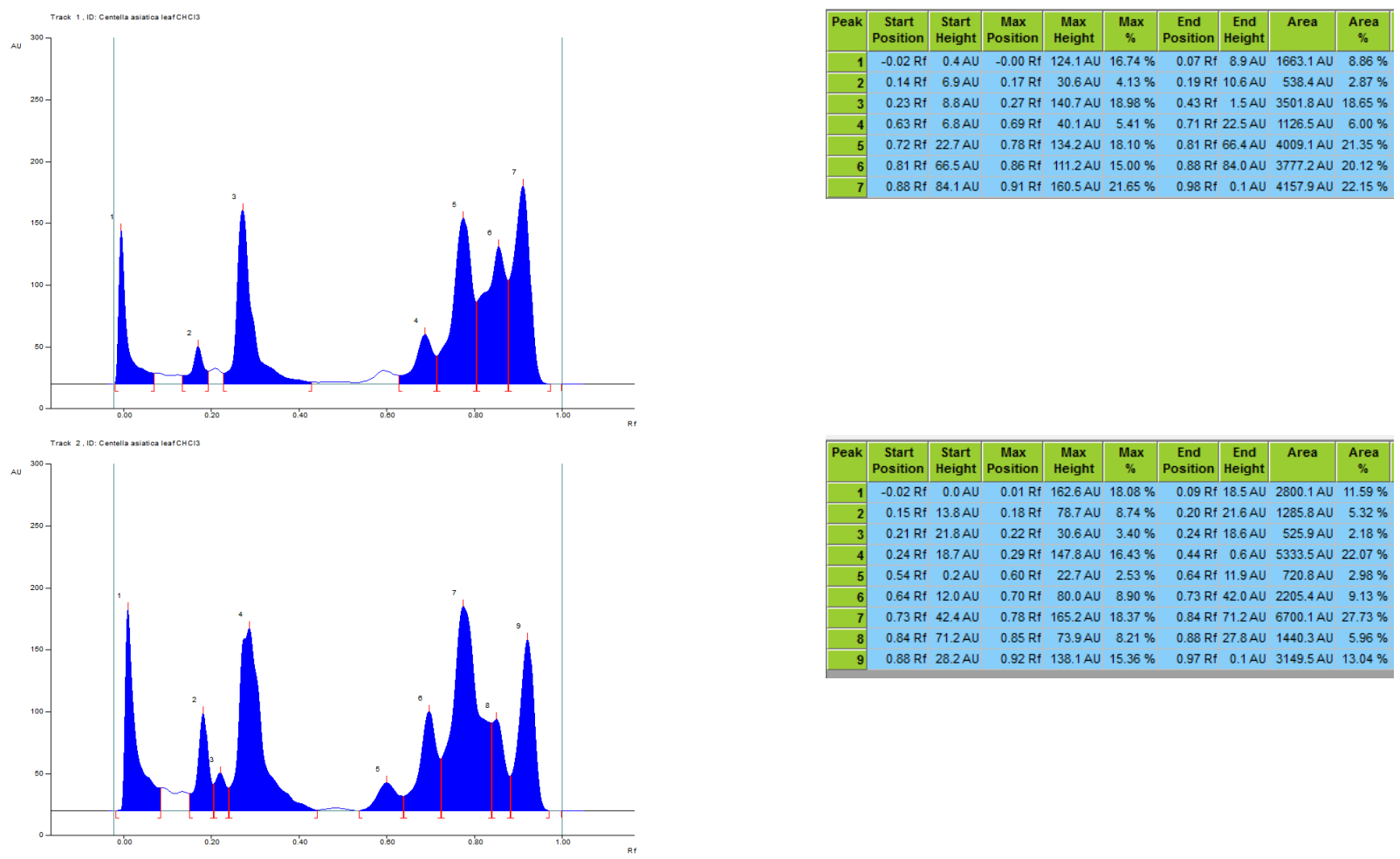

Fig. 8(2): Fingerprint profile and $\mathrm{R}_{\mathrm{f}}$ table of chloroform extract of $C$. asiatica (leaf) at $366 \mathrm{~nm}$

The HPTLC fingerprint profile and $\mathrm{R}_{\mathrm{f}}$ table of chloroform extract of leaves of $M$. emarginata and $C$. asiatica at UV $575 \mathrm{~nm}$ after
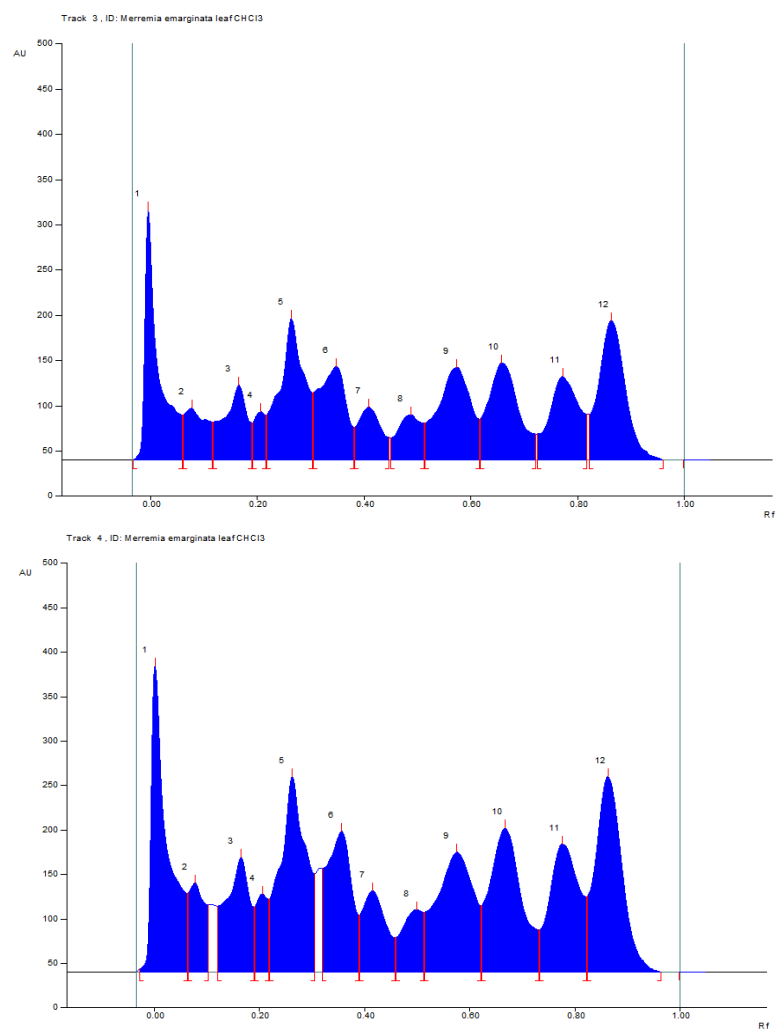

derivatization with vanillin-sulphuric acid are represented in fig. $9(1)$ and fig. 9(2) respectively.
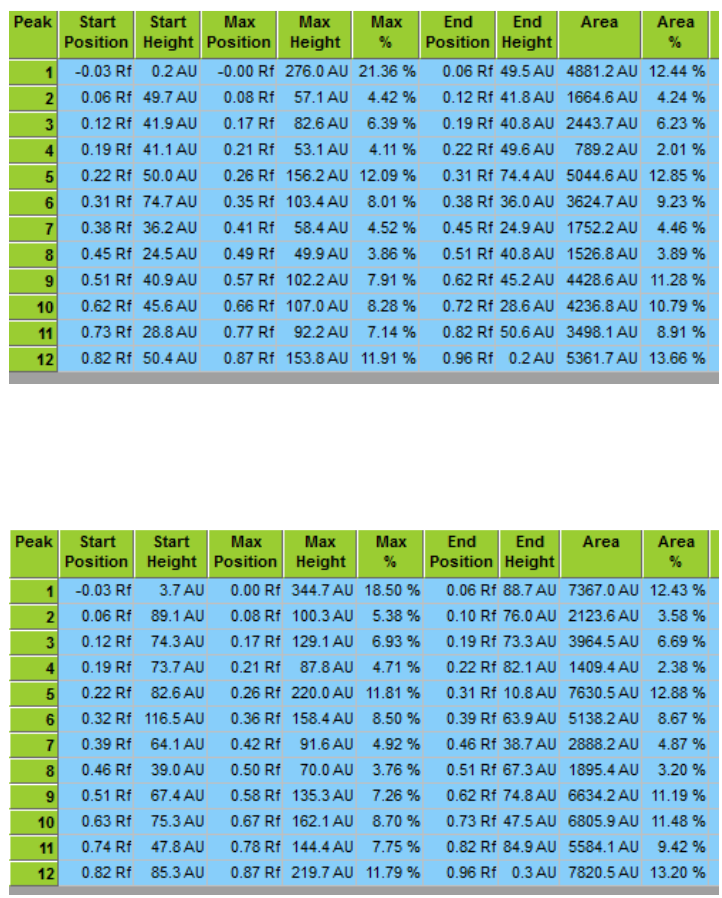

Fig. 9(1): Finger print profile and $R_{f}$ table of chloroform extract of $M$. emarginata (leaf) at $575 \mathrm{~nm}$ after derivatization 

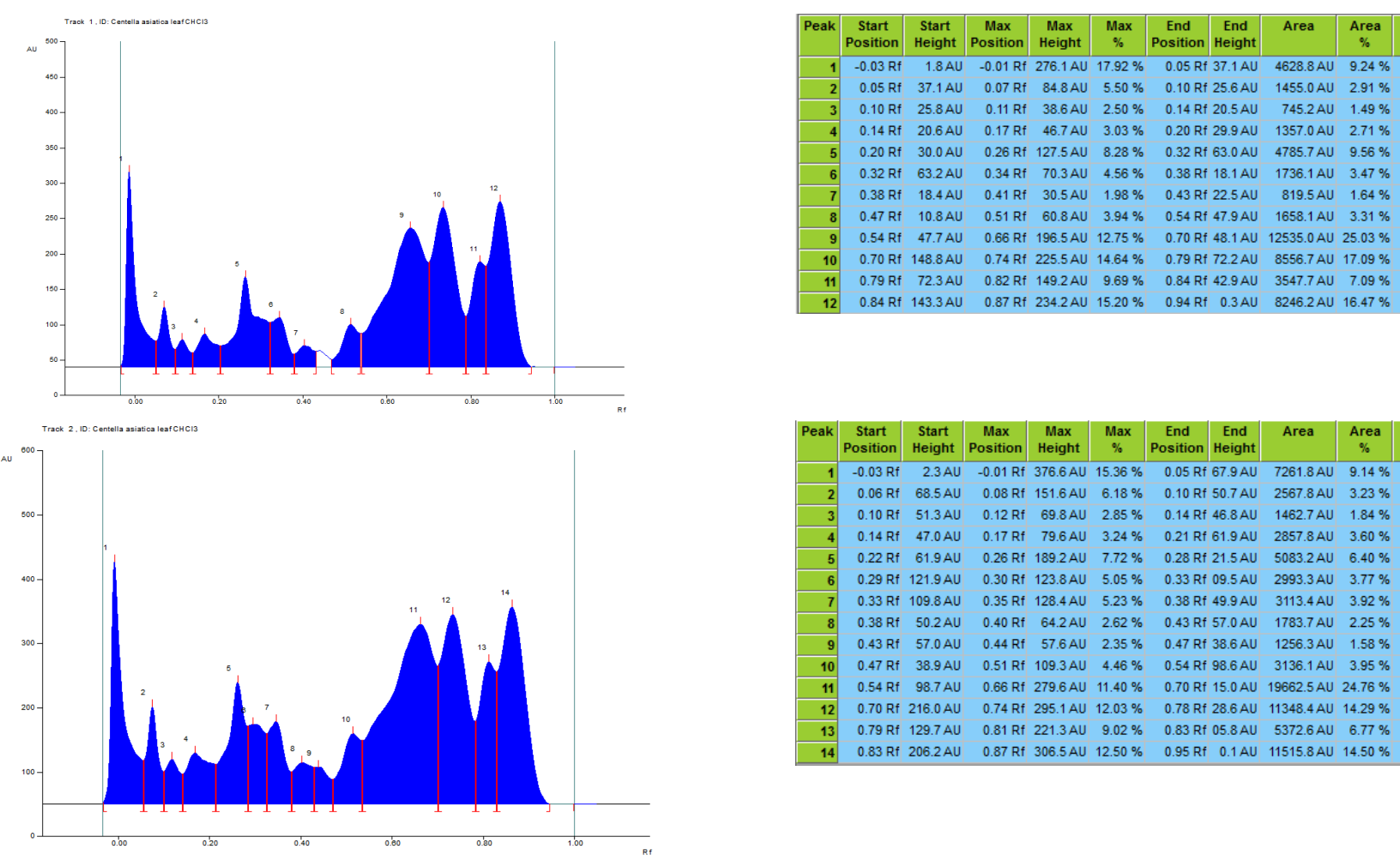

Fig. 9(2): Fingerprint profile and $R_{f}$ table of chloroform extract of $C$. asiatica (leaf) at $575 \mathrm{~nm}$ after derivatization

HPTLC for identification of chemical constituents in the plant extracts typically produces fingerprints, ie. sequence of zones that have specific positions, colours and intensity. The fingerprints obtained for the chloroform extracts of the leaves of M. emarginata and $C$. asiatica were compared and found that they are chemically different. These results are used to differentiate the two plant materials even though they are having similar morphological characteristics.

\section{CONCLUSION}

The macro and microscopical characters and HPTLC fingerprinting profile developed along with the physicochemical parameters can be used as a diagnostic tool to identify and to determine the quality and purity of the leaves of Merremia emarginata and Centella asiatica. HPTLC fingerprinting profile is a very important parameter of standardization for the proper identification of medicinal plants. The given results showed significant differences between the leaves of Merremia emarginata and Centella asiatica which help in accurate identification and thereby avoiding adulteration or substitution of these medicinally important plants.

\section{ACKNOWLEDGMENT}

The authors are highly thankful to the Director-General Prof. (Dr.) K. Kanakavalli, Central Council for Research in Siddha, Chennai for providing necessary facilities to carry out this work.

\section{AUTHORS CONTRIBUTIONS}

All the author have contributed equally

\section{CONFLICT OF INTERESTS}

Declare none

\section{REFERENCES}

1. Bown D. Encyclopaedia of herbs and their uses. London: Dorling Kindersley; 1995. p. 361-5.
2. Nadkarni AK. Dr. K. M. Nadkarni's Indian Material Medica. Bombay popular prakashan; 1982. p. 1229.

3. http://envis.frlht.org/plantdetails/048580ccb4ee657eddf1228 b869a024f/c30fc5062cf03808c4fc3b1245f3dc9b [Last accessed on 10 Jan 2019]

4. Nalini K, Aroor AR, Karanth KS, Rao A. Effect of Centella asiatica fresh leaf aqueous extract on learning memory and biogenic amine turnover in albino rats. Fitoterapia 1992;63:232-7.

5. Chopra RN, Nayar SL, Chopra IC. Glossary of Indian Medicinal Plants (Including the Supplement) New Delhi: Council of Scientific and Industrial Research; 1986. p. 51-83.

6. Diwan PC, Karwande I, Singh AK. Anti-anxiety profile of mandukparni Centella asiatica Linn in animals. Fitoterapia 1991;62:255-7.

7. Khandelwal KR, Nirali Prakashan. Practical pharmacognosy. 19th edn. Pune, India. Prakashan; 2008. p. 49-70.

8. Evans WC. Trease and evans pharmacognosy. 15th ed. London, United Kingdom: Saunders; 2002. p. 245-7.

9. Tyler V, Brady L, Robber J. Pharmacognosy, Varghese Company, India; 1977. p. 103-14.

10. WHO Quality control methods for medicinal plants materials. Geneva; 1998.

11. Camag. Application notes on instrumental thin layer chromatography; 2015. p. 1996.

12. Wagner $\mathrm{H}$, Bladt $\mathrm{S}$. Plant drug analysis-a thin layer chromatography atlas. Springer Verlage Berlin 1996;364:3-4.

13. Padmasornasubramanian M, Apprananthan T, Chelladurai V. Proceedings of the workshop on standardization of siddha drugs. Chennai: Central Research Institute Siddha; 1996.

14. Anonymous The Wealth of India. VI. New Delhi CSIR; 1962. p. 347.

15. Sudhakaran MV. Botanical pharmacognosy of holostemmaadakodien. Schult Pharmacogn J 2017;9:163-70.

16. Rizvi A, Mishra A, Mahdi AA, Wahab S, Kaleem S. Pharmacognostic evaluation and establishment of quality parameters of seeds of Cuminum cyminum L. Indian J Nat Prod Res 2015;6:138-42. 